\title{
Article
}

http://dx.doi.org/10.11646/phytotaxa.175.2.2

\section{Acantholimon riyatguelii (Plumbaginaceae), a threatened new unarmed species from Central Anatolia, Turkey}

\author{
HASAN YILDIRIM ${ }^{1} \&$ MANUEL B. CRESPO ${ }^{2 *}$ \\ ${ }^{I}$ Department of Biology, Faculty of Science, Ege University, 35100 Bornova, İzmir, Turkey; e-mail: hasanyldrm@gmail.com \\ ${ }^{2}$ CIBIO (Instituto Universitario de la Biodiversidad) \& Dpto. de Ciencias Ambientales y Recursos Naturales, Universidad de Alicante, \\ P.O. Box 99, ES-03080 Alicante, Spain; e-mail: crespo@ua.es \\ "Author for correspondence
}

\begin{abstract}
Acantholimon riyatguelii is described as a new species. Diagnostic morphological characters, a full description and detailed illustrations are provided on the basis of the type specimen and wild exemplars. This outstanding new species is a strict gypsophyte, which is characterized by the dwarf caespitose perennial habit, not forming dense thorny cushions; leaves are homomorphic, hairy, short and quite soft, not pungent but mucronate, swollen-fleshy and calcareous-punctate; spikes are unbranched, very compact, distichous, longer than leaves; spikelets are numerous and quite regularly imbricate; and the calyx is 5-lobed, with whitish limb. These combination of morphological characters in not known in any other Turkish Acantholimon species, and allows easy identification. The main morphological traits of $A$. riyatguelii suggest inclusion in $A$. sect. Staticopsis, though in an isolated position for which a new subsection, A. subsect. Exacantha, is described. Morphological affinities and divergences to other members of that section are dicussed. Furthermore, data are reported on the conservation status of $A$. riyatguelii, which is suggested to be labelled as CR according to the IUCN categories.
\end{abstract}

Key words: Acantholimon, Central Anatolia, conservation, endemisms, gypsophytes, sect. Staticopsis, subsect. Exacantha, taxonomy, Turkey

\section{Introduction}

The genus Acantholimon Boissier (1846: 69) includes perennial, densely or laxly pulvinate subshrubs forming thorny cushions. It is currently accepted to contain about 200 taxa, mainly distributed from southeastern Europe to Central Asia (Kubitzki 1993). The main distribution centres of the genus are located in the eastern Mediterranean and the IranoTuranian phytogeographic regions (Bokhari 1970), in which many narrow endemics occur. Taxa of Acantholimon have economic importance, mostly in gardening because the coloured and long-lasting flowers (Muvaffak et al. 2001).

The genus was first described (Boissier 1846) to segregate those species with pungent leaves and flowers arranged in spike-like or capitate inflorescences, which had formerly been referred to Statice Linnaeus (1753:274) nom. rej., or later to Statice subg. Armeriastrum Jaubert \& Spach (1843: 248). Subsequent monographic studies by Boissier (1848) and Bunge (1872) resulted in recognition of 74 species by the former in his Flora orientalis (Boissier 1879).

Taxonomic research undertaken during the last 40 years has notably improved the knowledge of Acantholimon in Turkey and the neighbouring areas. Bokhari $(1970,1972)$ performed comprehensive studies on Plumbaginaceae Juss., which led to description of six new Turkish Acantholimon species. The most recent treatment of the genus in Flora of Turkey (Bokhari \& Edmondson 1982) accepted 25 species, plus two imperfectly known species and nine doubtfully recorded ones. Further work carried out by Doğan \& Akaydın (2001, 2002a, 2002b, 2003, 2004, 2005), Akaydın \& Doğan (2002) and Akaydın (2004) resulted in the description of 12 new Turkish species. This remarkable effort was later completed by Doğan and Akaydın (2007), who named seven new taxa at different ranks, resurrected three species formerly treated in synonymy, and confirmed the occurrence of eight additional species in Turkey. In the latter contribution, Doğan and Akaydın (2007) presented a comprehensive synopsis of Turkish Acantholimon, in which they definitively recognized 52 species, 10 subspecies, and 17 varieties. On the basis of biometric analyses, Doğan et al. (2007) rearranged all those taxa in a new system including three sections and five subsections. 
A. riyatguelii is here assessed as "Critically Endangered" (CR) B2ab(i,ii,iii), on account of its restricted distribution in Turkey with an inferred severe decline of the extent of occurrence, the occupancy area and quality of the habitat. In consequence, this new Irano-Turanian element stands among other Turkish threatened endemic taxa of Acantholimon (cfr. Doğan et al. 2011).

Urgent legal measures should be implemented to ensure conservation of $A$. riyatguelii, which should be included in the red list of Turkish vascular plants. Similarly, the habitat in which it grows should also be protected, since gypseous outcrops of Central Anatolia host a remarkable phytodiversity with a high number of narrow endemics (cfr. Y1ldirıml 2012) in need of conservation.

\section{Diagnostic key for the subsections of Acantholimon sect. Staticoides}

1. Leaves fleshy, mucronate, not pungent, calcareous-punctate. subsect. Exacantha

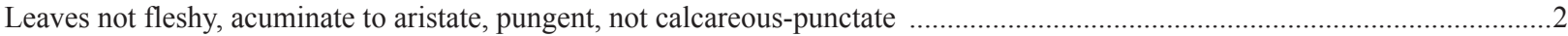

2. Remains of leaves of the previous year circinate; calyx limb reddish-brown or purplish (occasionally whitish) at anthesis ...........3

- $\quad$ Remains of leaves of the previous year not circinate; calyx limb whitish at anthesis ............................................................

3. Spikes (1-)2-5 ramose; spikelets densely arranged, the lowermost longer than rachis internodes ...................... subsect. Circinata Spikes simple; spikelets very laxly arranged, the lowermost shorter than rachis internodes................................. subsect. Robusta

4. Leaves linear-lanceolate, flat; inner bracts of the spikelets retuse-mucronate; calyx limb with excurrent ribs subsect. Dianthifolia Leaves usually triquetrous, subulate; inner bracts of the spikelets acute, usually aristate to cuspidate; calyx limb without excurrent ribs

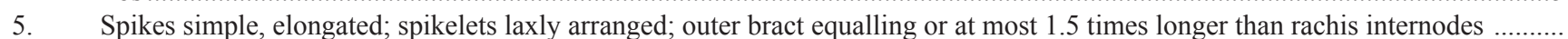
subsect. Caryophyllacea Spikes 2-branched (occassionally simple), usually short; spikelets densely arranged, imbricate or congested apically; outer bract at least twice longer than rachis internodes subsect. Androsacea

Additional specimens examined:- $\boldsymbol{A}$. anatolicum: TURKEY. A3 Ankara: Kuş Cenneti between Çayırhan and Nallıhan, deep gypseous sandy soil on mountain slopes, 500 m, 19 Aug 2000, Doğan 2007 \& Akaydın (ANKholotype!). A. avanosicum: TURKEY. B5 Nevsehir: between Avanos-Hacibektas, $3 \mathrm{~km}$ from Avanos, clay stone slopes, 950 m, 20 Aug 2000, Doğan 2052 \& Akaydın. (ANK-holotype!). A. birandii: TURKEY. C4 Karaman: On the road to Bucakkışla, $23 \mathrm{~km}$ from Karaman, 1350 m, 23 Aug 2000, Doğan 2081 \& Akaydın (ANK-holotype!). $\boldsymbol{A}$. confertiflorum: TURKEY. C4 Konya: Bozkır, on calcerous soil, 1100 m, 07 Sept 1949, Davis 16600 (E327026holotype!).A. dianthifolium: TURKEY. C10 Hakkari: Sat Da. (above Yüksekova), near permanent snow beds, patches of earth in the rocks, 2900 m, 28 Aug 1967, Duncan \& Tait 91 (E175344-holotype!). A. karamanicum: TURKEY. C4 Karaman: between Başyayla and Taşkent, Turanşah, calcareous mountain slopes in open Quercus cerris scrub, 1600 m, 24 Aug 2000, Akaydın 6518 \& Doğan (ANK-holotype!).

\section{Acknowledgements}

We are grateful to H. Duman (Gazi Üniversitesi), Z. Aytaç (Gazi Üniversitesi) and Ş. Yıldırımlı (Hacettepe Üniversitesi) for useful comments on the taxonomical status of the new species. Special thanks go to O. Erol (İstanbul Üniversitesi) for providing the SEM images of A. riyatguelii. We are also indebted to the curators of the herbaria $\mathrm{E}$ and $\mathrm{G}$ for digital images, and also ANK and EGE for the loan of plant material.

\section{References}

Akaydın, G. (2004) A new species of Acantholimon Boiss. Sect. Staticopsis Boiss. (Plumbaginaceae) from North Anatolia, Turkey. Nordic Journal of Botany 22(6): 679-682.

http://dx.doi.org/10.1111/j.1756-1051.2002.tb01926.x

Akaydın, G. \& Doğan, M. (2002) A new species of Acantholimon Boiss. (Plumbaginaceae) from Western Taurus Mountains of Turkey. Israel Journal of Plant Sciences 50: 67-71.

Akaydın, G. \& Doğan, M. (2012) Plumbaginaceae. In: Güner, A., Aslan, S., Ekim, T., Vural, M. \& Babaç, M.T. (Eds.) Türkiye Bitkileri Listesi (Damarlı Bitkiler). Nezahat Gökyiğit Botanik Bahçesi ve Flora Araştırmaları Derneği Yayını, İstanbul, pp. 684-690.

Baumgardt, E. (1816) Enumeratio stirpium magno Transsilvaniae 2. Comesiane, Wien, 392 pp. 
Böcük, H., Türe, C. \& Ketenoğlu, O. (2009) Plant diversity and conservation of the Northeast Phrygia Region under the impact of land degradation and desertification (Central Anatolia, Turkey). Pakistan Journal of Botany 41(5): 2305-2321.

Boissier (1844) Diagnoses plantarum orientalium novarum, ser. 1, 1(4). B. Herrmann, Leipzig, 86 pp.

Boissier, E. (1846) Diagnoses plantarum orientalium novarum, ser. 1, 1(7). B. Herrmann, Leipzig, 130 pp.

Boissier, E. (1848) Plumbaginaceae. In: Candolle, A.L.P. de (ed.), Prodromus systematis naturalis regni vegetabilis 12. V. Masson, Paris, pp. 617-696.

Boissier, E. (1849) Diagnoses plantarum orientalium novarum, ser. 1, 2(11). B. Herrmann, Leipzig, 136 pp.

Boissier, E. (1879) Flora orientalis 4(2). H. Georg, Genevae et Basileae, 995 pp.

Bokhari, M.H. (1970) Materials for a Flora of Turkey. XXII. Plumbaginaceae. Notes from the Royal Botanic Garden Edinburgh 30: 295-304.

Bokhari, M.H. (1972) Synopsis of Plumbaginaceae in Turkey. Notes from the Royal Botanic Garden Edinburgh 30: 57-77.

Bokhari, M.H. \& Edmondson, J.R. (1982) Acantholimon Boiss. In: Davis, P.H. (ed.), Flora of Turkey and the East Aegean Islands, 7. Edinburgh University Press, Edinburgh, pp. 478-502.

Bunge, A. (1872) Die Gattung Acantholimon Boiss. Mémoires de l'Académie impériale des sciences de St.-Pétersbourg Série 7, 18(2): $1-72$.

http://dx.doi.org/10.5962/bhl.title.41374

Cañadas, E.M., Ballesteros, M., Valle, F. \& Lorite, J. (2014) Does gypsum influence seed germination? Turkish Journal of Botany 38: $141-147$.

http://dx.doi.org/10.3906/bot-1305-19

Doğan, M. \& Akaydın, G. (2001) A new species, Acantholimon birandii (Plumbaginaceae), from the Central Anatolian Steppe in Turkey. Nordic Journal of Botany 21(5): 481-484. http://dx.doi.org/10.1111/j.1756-1051.2001.tb00800.x

Doğan, M. \& Akaydın, G. (2002a) A new species of Acantholimon Boiss. (Plumbaginaceae) from Central Anatolia, Turkey. Botanical Journal of the Linnean Society 138: 365-368.

Doğan, M. \& Akaydın, G. (2002b) A new species of Acantholimon Boiss. (Plumbaginaceae) from Ankara, Turkey. Botanical Journal of the Linnean Society 140: 443-448.

Doğan, M. \& Akaydın, G. (2003a) Two new species of Acantholimon sect. Staticopsis. (Plumbaginaceae) from Turkey. Annales Botanici Fennici 40: 53-58

Doğan, M. \& Akaydın, G. (2003b) An undescribed species of Acantholimon Boiss. Sect. Staticopsis Boiss. (Plumbaginaceae) from Turkey. Israel Journal of Plant Sciences 51: 231-236. http://dx.doi.org/10.1560/nugh-we3x-6f8p-6nt5

Doğan, M. \& Akaydın, G. (2004) Three new species with two flowered spikelets in Acantholimon (Plumbaginaceae) from East Anatolia, Turkey. Botanical Journal of the Linnean Society 144: 497-505. http://dx.doi.org/10.1111/j.1095-8339.2003.00267.x

Doğan, M. \& Akaydın, G. (2005) A new species of Acantholimon Boiss. sect. Glumaria Boiss. (Plumbaginaceae) from Elazı̆̆, Turkey. Botanical Journal of the Linnean Society 149: 351-356. http://dx.doi.org/10.1111/j.1095-8339.2005.00438.x

Doğan, M. \& Akaydın, G. (2007) Synopsis of Turkish Acantholimon Boiss. (Plumbaginaceae). Botanical Journal of the Linnean Society 154: 397-419. http://dx.doi.org/10.1111/j.1095-8339.2007.00663.x

Doğan, M., Duman, H. \& Akaydın, G. (2003) Taxonomy and conservation status of Acantholimon laxiflorum Boiss. ex Bunge (Plumbaginaceae). Turkish Journal of Botany 27: 447-452.

Doğan, M., Akaydın, G. \& Çakaroğullari, D. (2007) Infrageneric grouping of Turkish Acantholimon Boiss. (Plumbaginaceae) assessed by numerical taxonomy. Advances in Biological Research 1 (3-4): 85-91.

Doğan, H.M., Doğan, M., Akaydın, G. \& Celep, F. (2011) Mapping and analysing the diversity of the genus Acantholimon taxa in Turkey by geographic information systems (GIS). Turkish Journal of Botany 35: 91-110.

Dudley, T.R. (1964) Studies in Alyssum: Near Eastern representatives and their allies. Journal of the Arnold Arboretum 45: 57-95.

Erdoğan, N., Ketenoğlu, O., Bingöl, M.Ü., Geven, F. \& Arslan, M. (2011) Sivrihisar Dağları (Eskişehir/Türkiye) Vejetasyon Tiplerinin Floristik Kompozisyonu Üzerine Bir Araştırma. Mehmet Akif Ersoy Üniversitesi Fen Bilimleri Enstitüsü Dergisi 4: 1-11.

Huber-Morath, A. (1963) Novitiae florae anatolicae, VI. Bauhinia 2: 192-203.

Greuter, W. (1985). Dipsacaceae. In: Greuter, W. \& Raus, T. (Eds.) Med-Checklist notulae, 11. Willdenowia 15: 71-76.

Grierson, A.J.C. (1975) Materials for a flora of Turkey. XXXI. Anthemis. Notes from the Royal Botanic Garden Edinburgh 33: 428.

IUCN (2012) IUCN Red List Categories and Criteria: Version 3.1. $2^{\text {nd }}$ edition. IUCN Species Survival Commission, Gland, Switzerland and Cambridge, $32 \mathrm{pp}$. 
Jaubert, H.F. \& Spach, É. (1843) Conspectus subgeneris Armeriastrum. Annales des Sciences Naturelles, Botanique, ser. $220: 248-256$.

Kubitzki, K. (1993) Plumbaginaceae Lindl. In: Kubitzki, K., Rohwer, J.G. \& Bittrich, V. (Eds.) The families and genera of flowering plants. II. Flowering plants. Dicotyledons: Magnoliid, Hamamelid and Caryophyllid families. Springer, Berlin, pp. 523-530.

Ledebour, C.F. von (1847) Flora rossica 3(1). E. Schweizerbart, Stuttgartiae, 256 pp.

Lehmann, J.G.C. (1817) Beschreibung einiger neuen und wenig bekannten Pflanzen. Neue Schriften der naturforschenden Gesellschaft zu Halle 3(2): 1-26.

Linczevski, L.A. (1952) Plumbaginaceae Lindl. In: Shishkin, B.K. \& Bobrov, E.G. (eds.), Flora SSSR 18 (Metachlamydeae). Botanicheskii Institut Akademii Nauk SSSR, Moskva-Leningrad, pp. 292-474 [English translation: Israel Program for Scientific Translations, Jerusalem, 1967].

Linnaeus, C. (1753) Species plantarum 1-2. L. Laurentii Salvii, Holmiae, 1200 pp.

Merlo, M.E., Mota, J.F. \& Sánchez-Gómez, P. (2011) Ecofisiología y adaptaciones de las plantasvasculares a las características físicas y químicas de sustratos especiales. In: Mota, J.F., Sánchez-Gómez, P. \& Guirado, J.S. (Eds.) Diversidad vegetal de las yeseras ibéricas. El reto de los archipiélagos edáficos para la biología de la conservación. ADIF-Mediterráneo Asesores y Consultores, Almería, pp. 53-73.

Miller, Ph. (1768) Gardeners' dictionary, $8^{\text {th }}$ ed. J. \& F. Rivington, London, $1300 \mathrm{pp}$.

Mobayen, S. (1964) Revision taxonomique du genre Acantholimon. Imprimèrie Économiste, Téhéran, 336 pp.

Moore, D.M. (1972) Acantholimon Boiss. In: Tutin, T.G., Heywood, V., Burges, N.A., Moore, D.M., Valentine, D.H., Walters, S.M. \& Webb, D.A. (Eds) Flora europaea 3. Cambridge University Press, Cambridge, 30 pp.

Muvaffak, A., Doğan, M. \& Bilgin, C.C. (2001) Numerical taxonomic study of the genus Acantholimon Boiss. (Plumbaginaceae) in Ankara Province. Israel Journal of Plant Sciences 49: 297-300.

Nordmann, A. von (1837) Vorläufige Diagnosen einiger während einer naturwissenschaftlichen Reise im westlichen Theile der Kaukasischen Provinzen entdeckten und als neu erkannten Pflanzenspecies. Bulletin Scientifique Publie par l'Académie Imperiale des Sciences de Saint-Pétersbourg 2: 311-314.

Post, G.E. (1933) Flora of Syria, Palestine and Sinai. American Press, Beirut, 919 pp.

Rechinger, K.H. \& Schiman-Czeika, H. (1974) Plumbaginaceae. In: Rechinger, K.H. (Ed.) Flora Iranica 108. Akademische Druck-u Verlagsanstalt, Graz, 1-158 pp.

Rivas-Martínez, S. (2007) Mapa de series, geoseries y permaseries de vegetación de España (Memoria del Mapa de vegetación potencial de España,). Parte I. Itinera Geobotanica 17: 5-435.

Takhtajan, A. (1986) Floristic regions of the world. University of California Press, Berkeley-Los Angeles-London, 544 pp.

Thiers, B. (2014) Index Herbariorum: A global directory of public herbaria and associated staff. New York Botanical Garden's Virtual Herbarium. Available from: http://sweetgum.nybg.org/ih/ (accessed: 01 February 2014).

Willdenow, C.L. von (1798) Species Plantarum, $4^{\text {th }}$ ed. 1(2). G.C. Nauk, Berolini, 1071 pp.

Yıldırıml1, Ş. (2009) Miscellaneous nomenclatural and taxonomic corrections on Turkish plants, 2. Ot Sistematik Botanik Dergisi 16(1): 9-14.

Yıldırıml, Ş. (2012) The heaven of gypsophilous phytodiversity of Turkey: Kepen, Sivrihisar, Eskişehir, Turkey, 13 taxa as new. Ot Sistematik Botanik Dergisi 19(2): 1-51.

Zohary, M. (1973) Geobotanical foundations of the Middle East 1-2. Gustav Fischer Verlag, Stuttgart, 739 pp. 